2. Литвинова C. On-line навчальне середовище вчителя-предметника загальноосвітнього навчального закладу [Електронний ресурс]. - Режим доступу: http: //journal.iitta.gov.ua/ index.php/itlt/ article/ view/356/313UnJjrHC8DR4 3. Литвинова С. Віртуальна учительська за хмарними технологіями / Литвинова С. Г. // Комп'ютер у школі та сім’ї. - 2013. - № 2 (106) - С. 23-25. 4. Литвинова С. Віртуальні предметні спільноти / С. Г. Литвинова // Інформаційно-комунікаційні технології в освіті: досвід, інновації, технічне забезпечення : збірник матеріалів Всеукраїнської науково-практичної конференції (1-2 березня 2012 року м. Суми). - Суми : РВВ СОІППО, 2012. - С. 39-42. 5. Литвинова С. Хмарні технології: особливості діяльності вчителів-предметників у віртуальних предметних спільнотах / C. Г. Литвинова // Теорія та методика електронного навчання. Вип. IV. - Кривий Ріг : Видавничий відділ КМI, 2013. - С. 165-170. 6. Литвинова С. Хмаро орієнтоване середовище управління школою/ С. Г. Литвинова // Міжнародний науковий конгрес «Інформаційне суспільство в Україні». Тези доповідей. - Київ : Український Дім, 2013. - С. 64-66. 7. Національна стратегія розвитку освіти в Україні на період до 2021 року [Електронний ресурс]. - Режим доступу: http://www.president.gov.ua/ru/ documents/15828.html. 8. Парламентські слухання «Доступність та якість загальної середньої освіти : стан і шляхи поліпшення» [Електронний ресурс]. - Режим доступу: http://www.mon.gov.ua .

УДК 37:316.77

Ірина Онищенко

\title{
СУТНІСТЬ І СТРУКТУРА ІНФОРМАЦІЙНО-КОМУНІКАЦІЙНОГО ПЕДАГОГІЧНОГО СЕРЕДОВИЩА
}

Онищенко I. B. Сутність i структура інформаційно-комунікаційного педагогічного середовища.

У статті розкрито сутність інформаційно-комунікаційного педагогічного середовища, визначено його роль у професійній підготовці майбутніх педагогів. Обгрунтовано думку про те, що інформаційно-комунікаційне педагогічне середовище $\epsilon$ складною педагогічною системою, яка охоплює інформаційні, організаційні, інтелектуальні, методичні, технічні, програмні ресурси й підвищує ефективність та якість підготовки фахівців.

Ключові слова: інформатизація освіти, інформаційне середовище, інформаційно-комунікаційне педагогічне середовище, інформаційно-комунікаційні технології, професійна підготовка.

Онищенко И. В. Сущность и структура информационно-коммуникационной педагогической среды.

В статье раскрыта сущность информационно-коммуникационной педагогической среды, определена ее роль в профессиональной подготовке будущих педагогов. Обосновано мнение о том, что информационнокоммуникационная педагогическая среда является сложной педагогической системой, которая включает информационные, организационные, интеллектуальные, методические, технические, программные ресурсы и повышает эффективность и качество подготовки специалистов. 
Ключевые слова: информатизация образования, информационная среда, информационно-коммуникационная педагогическая среда, информационнокоммуникационные технологии, профессиональная подготовка.

Onishchenko I. V. The essence and structure of information and communication pedagogical environment.

The article reveals the essence of information and communication pedagogical environment, defined by its role in the training of future teachers. The opinion that the information and communication environment is a complex pedagogical educational system, which includes the information, organizational, intellectual, methodological, technical, program resources that increase efficiency and the quality of specialists' training.

Key words: information education, information environment, information and communication pedagogical environment, information and communication technologies, professional training.

В умовах інформатизації освіти сучасний ВНЗ має перетворитися із замкнутої професійної системи на відкриту систему 3 великою кількістю інформаційних ресурсів, джерел навчальної інформації, здатного задовольнити вмотивовані запити і потреби майбутнього фахівця. Інформаційне суспільство висуває нові вимоги до професійних якостей майбутнього педагога: сьогодення вимагає не лише глибоких фундаментальних теоретичних знань, відповідної практичної підготовки, але й наявність навичок користування сучасною оргтехнікою, програмним забезпеченням, вміння використовувати сучасні інформаційні технології у професійній діяльності.

Аналіз стану використання IКТ у процесі фахової підготовки майбутніх педагогів є свідченням того, що інформаційні засоби на заняттях із психологопедагогічних дисциплін використовуються фрагментарно, відсутні методичні рекомендації щодо їх ефективного використання, студенти мають низький рівень мотивації до професійної діяльності, не вміють вільно використовувати сучасні досягнення науки й техніки, зокрема в галузі інформаційних технологій, у них відсутній інтерес до самостійного оволодіння фаховими знаннями.

Вимога радикального підвищення ефективності та якості підготовки фахівців до рівня, досягнутого в розвинутих європейських країнах, активне використання сучасних ІКТ вимагає побудови принципово нового типу навчального середовища, забезпечення якого сприятиме не лише наданню фахових знань, а й навчить сучасних студентів керувати інформаційними потоками, обробляти їх, користуватися інтернет-ресурсами для ефективного навчання, створювати власні мультимедійні матеріали засобами IКТ.

Сформувати особистість із позитивною мотивацією до професійної діяльності, конкурентоспроможного фахівця, здатного до творчої праці, самостійного й нестандартного розв'язання складних проблем у педагогічній практиці дозволить нове навчальне середовище - інформаційно-комунікаційне педагогічне середовище. Це середовище забезпечує інформаційну підтримку навчального процесу у ВНЗ, збагачує та доповнює систему традиційних форм та методів навчання, підвищує результативність проведення наукових досліджень, створює умови задля професійного спілкування.

Ключові проблеми інформатизації освіти як складової інформатизації суспільства, дидактико-педагогічні й методичні проблеми інформатизації 214 Педагогіка вищої та середної иколи. - 2014. - Вип. 40. 
навчального процесу ВНЗ розкрито в дослідженнях В. Бикова, В. Болтянського, А. Верланя, Б. Гершунського, А. Гуржія, Ю. Дорошенка, А. Сршова, М. Жалдака, Ю. Жука, М. Кадемії, А. Коломієць, В. Монахова, Н. Морзе, Б. Наумова, I. Підласого, О. Пєхоти, Л. Пєтухової, Ю. Рамського, В. Розумовського, С. Семерікова, О. Співаковського, Ю. Триуса, О. Трофімова, В. Шакотька, О. Шиман та ін.

Аналіз наукової літератури свідчить про значний інтерес до питань створення й функціонування інформаційного середовища у ВНЗ, розкриття його сутності, різновидів, особливостей, функцій, структури, можливостей (Ю. Атаманчук, О. Андреєв, Т. Білоочко, В. Биков, А. Верлань, Н. Воропай, Р. Гіляревський, Н. Гіченко, Г. Гордійчук, Р. Гуревич, А. Гуржій, М. Жалдак, М. Жукова, М. Кадемія, Ю. Караван, Н. Карпович, Д. Касаткін, Л. Коношевський, О. Коношевський, С. Лещук, С. Ляшенко, Г. Омельяненко, О. Співаковський, Н. Тимофєєва, О. Щолок, С. Яшанов та ін.).

Теоретико-методологічні засади професійної підготовки майбутніх педагогів в умовах інформаційного середовища ВНЗ досліджували С. Гунько, Ю. Дорошенко, С. Колесніков, А. Коломієць, В. Кондратова, О. Кравчук, М. Левшин, Н. Листопад, Г. Ломаковська, Д. Мазока, О. Майборода, А. Макаренко, М. Овчиннікова, І. Парасюк, Ю. Первін, Л. Петухова, Н. Полька, Й. Ривкінд, Ф. Ривкінд, А. Семенов, О. Снігур, О. Співаковський, О. Суховірський, В. Шевченко та ін. Аналіз праць науковців переконує, що професійне становлення майбутнього педагога відбувається в умовах інформаційного середовища, яке дозволяє формувати в майбутніх фахівців інформаційну культуру, підвищує комп'ютерну грамотність, розширює інформаційно-освітній простір.

Проте, дослідження не розкривають сутності інформаційно-комунікаційного педагогічного середовища, не визначають його компонентну структуру, не описують можливі шляхи інтеграції й уніфікації інформаційних ресурсів, які входять до складу окресленого середовища. Отже, можна констатувати, що окреслена проблема залишається недостатньо дослідженою, актуальною та потребує детального вивчення.

Mema cmammi полягає в тому, щоб акцентувати увагу на розгляді сутності і структури інформаційно-комунікаційного педагогічного середовища ВНЗ.

У сучасних умовах спостерігаємо активне занурення студентів у нове глобальне (переважно стихійне) віртуальне інформаційне середовище, створене за допомогою використання персональних комп'ютерів, планшетів, мобільних телефонів, електронних книг тощо. Незалежно від того, як організовано у ВНЗ електронне навчання, сучасні студенти активно користуються інтернет-ресурсами, електронними бібліотеками, електронними підручниками, електронними посібниками, засобами комп'ютерного тестування. За доступністю й обсягом інформації електронні ресурси набагато випереджають традиційні паперові носії, але питання якості поданої в них інформації залишається відкритим. У новому інформаційному середовищі кожен учасник навчально-виховного процесу має вільно орієнтуватися, ефективно використовувати інформацію задля освітніх потреб.

Отже, найважливішим завданням ВНЗ $є$ створення інформаційного середовища, що забезпечуватиме високу якість електронного контенту, навчить студентів орієнтуватися в ньому, зберігати, відтворювати i продукувати інформацію, стимулюватиме до активного учіння. Якісне інформаційне середовище, на думку Г. Гордійчук та Д. Зінченко, сприяє «логічному впорядкуванню 
інформації, іï систематизації і структуруванню, створює передумови для виходу на новий технологічний рівень навчальних технологій, новий рівень одержання наукових знань, підвищує конкурентоспроможність програм вищої освіти» [1, c. 311].

На нашу думку, формуванню сучасного фахівця педагогічної галузі сприяє створення нового типу інформаційного середовища - інформаційнокомунікаційного педагогічного середовища. Окреслене середовище дає змогу організувати навчальний процес на високому професійному рівні, забезпечує нові шляхи надання інформації, створює умови для гуманізації навчання на основі творчого й діяльнісного підходів, розвитку креативної особистості, формування позитивної мотивації до навчання.

Поняттю «інформаційно-комунікаційне педагогічне середовище» передували такі поняття, як: «освітнє середовище», «інформаційне середовище», «інформаційно-комунікаційне середовище», «інформаційно-освітнє середовище», «інформаційно-навчальне середовище».

В умовах інформатизації вищої педагогічної освіти закономірним явищем є трансформація «освітнього середовища» в «інформаційно-комунікаційне педагогічне середовище». Поняття «інформаційно-комунікаційне педагогічне середовище» вперше введено Л. Пєтуховою як «сукупність знаннєвих, технологічних і ментальних сутностей, які в синхронній інтеграції забезпечують якісне оволодіння системою відповідних знань» [4, с. 156]. Під сутністю дослідниця розуміє «те постійне, що зберігається в явищі за різних варіацій, у тому числі і часових. Це невід'ємна якість, без якої предмет неможливо мислити» [4, с. 156]. Ключові сутності, що становлять основу поняття «інформаційно-комунікаційне педагогічне середовище», Л. Пєтухова розглядає як: «знаннєві сутності - це особистісні системи набутих і сформованих знань; технологічні сутності - це технічні, програмні, мережні засоби отримання, зберігання, опрацювання та подання інформації; ментальні сутності - передбачають дотримання сукупності психічних, інтелектуальних, ідеологічних, релігійних, естетичних й інших особливостей народу» [4, с. 156].

За результатами досліджень Л. Пєтухової, інформаційно-педагогічне середовище у ВНЗ сприяє кардинальним змінам в організації професійнопедагогічної підготовки вчителя, спонукає до засвоєння нової інформації, видів діяльності, вимагає систематичного поповнення знань, бажання самовдосконалення. Водночас майбутній педагог розширює свої можливості доступу до світових інформаційних ресурсів, поглиблює інформаційний обмін і трансформацію одержаної інформації, розвиває особистісні інтелектуальні якості, свою інформатичну компетентність [4, с. 245].

Ми визначаємо інформаційно-комунікаційне педагогічне середовище як складну систему, що акумулює інформаційні, організаційні, інтелектуальні, методичні, технічні і програмні ресурси; сприяє інформаційно-навчальній взаємодії моделі «викладач - студент - середовище».

Основне призначення інформаційно-комунікаційного педагогічного середовища - забезпечення віддаленого відкритого, повноцінного, інтерактивного доступу до всіх освітніх ресурсів ВНЗ (навчальна, методична, довідкова, нормативна, організаційна й інша інформація). При цьому віддалений доступ розуміється як доступність інформації для викладачів, співробітників, студентів і слухачів, як у ВН3, так і за його межами, у будь-який час, у режимах on- i off-line [5, c. 18]. Освітнє середовище виконує такі основні функції: інформаційну, навчальну, 
виховну, мотиваційну, діагностичну, розвиваючу, організаційну, корекційну, контролюючу.

В аспекті нашого дослідження важливим завданням $\epsilon$ визначення структурних компонентів інформаційно-комунікаційного педагогічного середовища. Структуру різних видів інформаційного середовища досліджували Н. Воропай, В. Коткова, Л. Пєтухова, Л. Полякова, І. Розіна, О. Щолок та ін.

Л. Пєтухова 3-поміж складників інформаційно-комунікаційного педагогічного середовища виокремлює комп'ютерні й інформаційні технології навчання, педагогічні програмні засоби, створення спеціального програмного середовища 3 необхідними для студента дидактичними, методичними матеріалами, творчими завданнями, використання елементів автоматизації управління навчальним процесом і обов'язкового надання можливості роботи з ресурсами глобальної мережі Інтернет [3, с. 19]. На думку дослідниці, інформаційно-комунікаційне педагогічне середовище слід розглядати як здатну до саморозвитку системно організовану сукупність засобів передачі даних, інформаційних ресурсів, протоколів взаємодії, апаратно-програмного та організаційно-методичного забезпечення, орієнтовану на задоволення освітніх потреб користувачів, що охоплює дидактичні, методичні матеріали, творчі завдання, елементи автоматизації управління навчальним процесом і обов'язкового надання можливості роботи 3 ресурсами глобальної мережі Інтернет [4, с. 393-394].

На думку В. Коткової, змістовим наповненням компонентів інформаційнокомунікаційного педагогічного середовища мають бути: технічне середовище (персональні комп'ютери студентів або комп'ютерний клас); програмоване середовище (сукупність стандартних програм комп'ютерного користувача, Інтернет); предметне середовище (моделювання цілісних фрагментів педагогічної діяльності); методичне середовище (інструкції, алгоритми, методичні рекомендації взаємодії викладачів і студентів засобами ІКТ, порядок використання, оцінка ефективності тощо) [2, с. 104].

О. Щолок, досліджуючи структуру інформаційно-навчального середовища, виокремлює такі блоки: інформаційний (система знань й умінь студента); пізнавальний (властивості, зміст і впливові чинники пізнавальної діяльності); ціннісно-цільовий (сукупність цілей $\mathrm{i}$ цінностей освіти, значущих в аспекті досягнення поставленої мети); технологічний (засоби нових інформаційних технологій); комунікативний (форми взаємодії між учасниками педагогічного процесу); організаційно-методичний (сукупність можливих стратегій, форм, програм і методів організації навчально-інформаційної взаємодії) [7, с. 183-184].

Відповідно, І. Розіна побудувала об'єктно-орієнтовану модель інформаційнокомунікаційного середовища, 3-поміж структурних компонентів якої виокремлює: користувачів (викладачі, учні й інші учасники педагогічного процесу, провайдери освітніх послуг), правила взаємодії (передбачені комп'ютерною програмою, курсом, інтуїтивні, етичні), події (здійснювані користувачами дії та їхні результати), інформаційні об'єкти (тексти, графіка, відеозаписи, з якими працюють користувачі). Побудова моделі окресленого середовища враховувала п'ять ознак: інтегративну цілісність, багатокультурність та багатоплановість, надмірність (позитивна), відкритість, мовну (лінгвістичну) спрямованість [6].

На нашу думку, інформаційно-комунікаційне педагогічне середовище повинно будуватися відповідно до таких принципів: відкритість, доступність, мультимедійність, мобільність, безперервність, оперативність, продуктивність, 
інтерактивність, багатокомпонентність, інтегральність, інтелектуальність, адаптивність, розподіленість, демократичність, індивідуальність.

Аналізуючи погляди науковців на структуру інформаційно-комунікаційного педагогічного середовища, вважаємо за необхідне розглядати його як складну систему технічних і програмних засобів, організаційного, методичного, апаратнопрограмного та математичного забезпечення, об'єднаного за допомогою мережевих технологій. Інформаційно-комунікаційне педагогічне середовище - це багатокомпонентне середовище, що передбачає такі мікросередовища: технічне (комп'ютерна техніка: персональний комп'ютер, планшет тощо), програмоване середовище (Інтернет), предметне (моделі різних напрямків та елементів педагогічної діяльності), методичне (навчально-методичні матеріали, методичні рекомендації, інструкції тощо). Наявність розвинутого інформаційнокомунікаційного педагогічного середовища у ВНЗ дозволяє студенту оперативно звертатися до інформаційних ресурсів, джерел навчальної інформації, скорочує витрати часу на пошук потрібної інформації.

Так, Л. Полякова зазначає, що ефективна побудова інформаційного освітнього середовища ВНЗ на основі сучасних інформаційних технологій привносить у навчальний процес нові можливості: сполучення високої економічної ефективності та гнучкості навчального процесу, широке використання інформаційних ресурсів, істотне розширення можливостей традиційних форм навчання, можливість побудови нових ефективних форм навчання [5, с. 18].

Проведене дослідження $\epsilon$ свідченням того, що створення та ефективне функціонування інформаційно-комунікаційного педагогічного середовища у ВН3 сприяє формуванню в майбутніх педагогів власного інформаційного простору, інформаційного світогляду, інформаційної культури, самоосвітньої компетентності, професійної мобільності, потреби у професійному саморозвитку й самовдосконаленні.

Отже, створення у ВН3 інформаційно-комунікаційного педагогічного середовища є стратегічним напрямом підвищення ефективності та якості підготовки майбутніх педагогів. Окреслене середовище становить сутність інформаційних, організаційних, інтелектуальних, методичних, технічних і програмних ресурсів, які забезпечують інформаційну підтримку навчального процесу у ВН3, учать сучасних студентів керувати інформаційними потоками, ефективно користуватися інтернетресурсами відповідно до освітніх запитів і потреб.

\section{Література}

1. Гордійчук Г. Б. Використання інформаційного освітнього середовища навчального закладу для підготовки педагогів / Г. Б. Гордійчук, Д. В. Зінченко // Актуальні проблеми математики, фізики і технологічної освіти : зб. наук. праць. Вип. 7. - Вінниця : Планер, 2010. - С. 309-311. 2. Коткова В. Підготовка майбутнього фахівця початкової школи в умовах інформаційно-комунікаційного педагогічного середовища / В. Коткова // Психолого-педагогічні проблеми сільської школи : зб. наук. праць Уманського держ. педагог. у-ту ім. Павла Тичини. - Умань : ПП Жовтий, 2010. - Вип. 35. - С. 101-107. 3. Петухова Л. С. Теоретичні основи підготовки вчителів початкових класів в умовах інформаційно-комунікаційного педагогічного середовища : [монографія]/ Л. С. Петухова. - Херсон : Айлант, 2007. - 220 с. 4. Петухова Л. С. Теоретико-методичні засади формування інформатичних компетентностей майбутніх учителів початкових класів : дис. ... д-ра пед. наук : 13.00.04 / Л. Є. Петухова; Херсон. держ. ун-т. - Херсон, 2009. - 564 с. 5. Полякова Л. П. Державне управління інформаційно-освітнім середовищем 
інноваційних університетських комплексів : автореф. дис. на здобуття наук. ступеня д-ра наук 3 державного управління : 25.00.02 / Л. П. Полякова; Донец. держ. ун-т управління. - Донецьк, 2010. - 36 с. 6. Розина И. Н. Педагогическая компьютерноопосредованная коммуникация как прикладная область коммуникативных исследовании [Электронный ресурс]/ И. Н. Розина. - Режим доступа: http://ifets.ieee.org/ Russian/depository/v8_ 12/html 7. Щолок О. Б. Інформаційнонавчальне середовище як чинник формування компетентності самоосвіти у майбутнього фахівця / О. Б. Щолок // Освітнє середовище як методична проблема: [зб. наук. праць]. - Херсон : Вид-во ХДУ. - 2006. - С. 183-184.

Юлія Остраус

\section{ДЕЯКІ ПІДХОДИ ДО ВИЗНАЧЕННЯ СУТНОСТІ ПОНЯТТЯ «ПРОФЕСІЙНЕ САМОВДОСКОНАЛЕННЯ МАЙБУТНІХ СІМЕЙНИХ ЛІКАРІВ»}

Остраус Ю. М. Деякі підходи до визначення сутності поняття «професійне самовдосконалення майбутніх сімейних лікарів».

У статті здійснено теоретичний аналіз підходів науковців-педагогів до тлумачення понять «самовдосконалення» та «професійне самовдосконалення», розкрито сутність поняття «професійне самовдосконалення майбутніх сімейних лікарів».

Ключові слова: самовдосконалення, професійне самовдосконалення, самовиховання, професійне самовдосконалення майбутніх сімейних лікарів.

Остраус Ю. М. Некоторые подходы к определению сущности понятия «профессиональное самосовершенствование будущих семейных врачей».

В статье представлен теоретический анализ подходов ученых-педагогов к толкованию понятий «самосовершенствование» и «профессиональное самосовершенствование», раскрывается сущность понятия «профессиональное самосовершенствование будущих семейных врачей».

Ключевые слова: самосовершенствование, профессиональное самосовершенствование, самовоспитание, профессиональное самосовершенствование будущих семейных врачей.

Ostraus Y. M. Some approaches to the definition of the notion «future family doctor's professional self-improvement».

The author analyses the pedagogical approaches to the definition of the terms «selfimprovement» and «professional self-improvement». The meaning of the notion «future family doctor's professional self-improvement» is defined.

Key words: self-improvement, professional self-improvement, self-discipline, future family doctor's professional self-improvement.

Проблема підвищення якості підготовки майбутніх сімейних лікарів стала особливо актуальною на сучасному етапі розвитку нашої країни, коли розпочато роботу 3 реформування системи охорони здоров'я України. Модернізація всієї галузі тісно пов'язана з переходом до сімейної медицини, який дозволить зробити охорону здоров'я більш гнучкою, конкурентною і наближеною до потреб пацієнтів. Належне функціонування первинної ланки медичної допомоги повністю залежить від сімейних лікарів, які повинні мати більш високу кваліфікацію, ніж звичайні 